\title{
SPATIAL PATTERN ANALYSIS DAN SPATIALAUTOCORRELATION PRODUK DOMESTIK REGIONAL BRUTO (PDRB) SEKTOR INDUSTRI UNTUK MENGGAMBARKAN PEREKONOMIAN PENDUDUK DI JAWA TIMUR
}

\author{
*( Diah Ayu Novitasari \\ Fakultas Ekonomi \\ Universitas Islam Lamongan
}

\begin{abstract}
ABSTRAK
Produk Domestik Regional Bruto (PDRB) sektor industri adalah indikator yang menggambarkan keadaan perekonomian penduduk di suatu wilayah/daerah berdasarkan sektor industri. Penelitian ini akan menganalisis tingkat kecenderungan PDRB sektor industri dalam rangka ingin mengetahui sebaran PDRB DI Jawa Timur dan adanya dependensi PDRB antar wilayah di Jawa Timur. Metode yang digunakan adalah spatial pattern analysis dan spatial autocorrelation. Hasilnya menunjukkan bahwa pola sebaran proporsi PDRB di Jawa timur cenderung mengelompok (Cluster), yaitu mengelompok di kabupaten-kabupaten tertentu. Sementara hasil pengujian dengan Moran's I menunjukkan bahwa tidak ada autokorelasi spasial pada data proporsi PDRB di Provinsi Jawa Timur. Sementara secara lokal, kabupaten yang memiliki autokorelasi spasial hanyanyalah kabupaten yang memiliki autokorelasi spasial hanyanyalah Kabupaten Bangkalan, Pamekasan, Sampang, dan Sidoarjo.
\end{abstract}

Kata Kunci: PDRB, Perekonomian, Spatial Pattern, Spatial Autocorrelation, dan Moran's

\section{PENDAHULUAN}

Industri adalah suatu usaha atau kegiatan pengolahan bahan mentah atau barang setengah jadi menjadi barang jadi yang memiliki nilai tambah untuk mendapatkan keuntungan. Hasil industri tidak hanya berupa barang, tetapi juga dalam bentuk jasa. Faktor-faktor pokok yang menyebabkan suatu industri atau perindustrian dapat berkembang dengan baik adalah modal, tenaga kerja, bahan baku, sarana transportasi, sumber energi industri dan pemasaran produk hasil keluaran. Adapun faktor penunjang industri adalah kebudayaan masyarakat, teknologi, pemerintah, dukungan masyarakat, kondisi alam dan kondisi perekonomian[1].

Jawa Timur merupakan salah satu provinsi industri terbesar dan merupakan provinsi yang memiliki jumlah kabupaten/kota terbanyak yaitu sebanyak 38 kabupaten/kota. Jawa timur menjadi pusat industri dikarenakan infrastruktur yang ada sangat menunjang bagi pertumbuhan industri baik industri kecil, menengah maupun besar. Sektor industri Jawa Timur secara kontinu terus berkembang menjadi salah satu barometer di tingkat nasional. Tahun 2001 Jawa Timur memprogramkan pertumbuhan industri pada lima tahun mendatang ratarata pertahun akan dapat mencapai $9 \%$, dimana sektor industri diharapkan dapat memberikan sumbangan $27,47 \%$ dari struktur ekonomi yang ada di Jawa Timur.

Produk domestik regional bruto (PDRB) sektor industri adalah indikator yang menggambarkan keadaan perekonomian penduduk di suatu wilayah/daerah berdasarkan sektor industri. PDRB sektor industri Jawa Timur tahun 2005, 2006, 2007, 2008 dan 2009 mengalami pertumbuhan sebesar $54,3 \%$, $13,7 \%, \quad 11,8 \%, \quad 14,6 \%$ dan $8,9 \%$. Pertumbuhan PDRB sektor industri Jawa 
Timur tahun 2006 lebih rendah jika dibandingkan dengan tahun 2005 yaitu sebesar $54,3 \%$.

Sektor industri di Jawa Timur adalah sektor yang menyumbangkan output terbesar bagi perekonomian Jawa Timur [10]. Penelitian ini akan menganalisis tingkat kecenderungan PDRB sektor industri dalam rangka ingin mengetahui sebaran PDRB dan adanya dependensi perekonomian antar wilayah di Jawa Timur. Metode yang digunakan adalah spatial pattern analysis dan spatial autocorrelation. Metode ini sangat efektif dalam mendeteksi variasi secara geografi [11].

\section{TINJAUAN PUSTAKA \\ Produk Domestik Regional Bruto}

Produk Domestik regional Bruto (PDRB) adalah merupakan salah satu indikator pertumbuhan ekonomi suatu negara, wilayah, atau daerah. Pertumbuhan tersebut dapat dipengaruhi oleh beberapa faktor diantaranya infrastruktur ekonomi. PDRB adalah jumlah nilai tambah bruto yang dihasilkan seluruh unit usaha dalam wilayah tertentu atau merupakan jumlah nilai barang dan jasa akhir yang dihasilkan oleh seluruh unit ekonomi. PDRB atas dasar harga berlaku menggambarkan nilai tambah barang dan jasa yang dihitung dengan menggunakan harga pada setiap tahun, sedangkan PDRB atas dasar harga konstan menunjukkan nilai tambah barang dan jasa yang dihitung menggunakan harga pasa satu tahun tertentu sebagai tahun dasar penghitungannya. PDRB atas dasar harga berlaku dapat digunakan untuk melihat pergeseran strukturekonomi, sedangkan harga konstan dapat digunakan untuk mengetahui pertumbuhan ekonomi dari tahun ke tahun. Dengan demikian, PDRB merupakan indikator untuk mengatur keberhasilan pemerintah dalam memanfaatkan sumber daya yang ada, dan dapat digunakan sebagai perencanaan dan pengambilan keputusan.

\section{Spasial Pattern}

Spatial pattern atau pola spasial adalah sesuatu yang berhubungan dengan penempatan objek atau susunan benda di permukaan bumi. Setiap perubahan spatial pattern akan mengilustrasikan proses spasial yang ditunjukkan oleh faktor lingkungan atau budaya. Tiga pola dasar spasial yang telah diakui, yaitu: acak (random), mengelompok (clumped atau aggregated) dan seragam atau merata (uniform) [3] [7].

a. Random : Beberapa titik terletak secara random di beberapa lokasi. Posisi suatu titik tidak dipengaruhi oleh posisi titik lainnya.

b. Uniform: Setiap titik berada secara merata dan berjauhan dengan titiktitik lainnya.

c. Clustered: Beberapa titik membentuk suatu kelompok dan saling berdekatan.

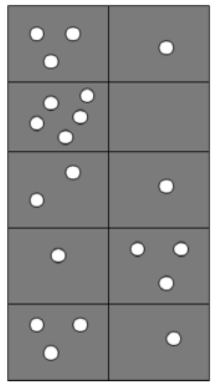

random

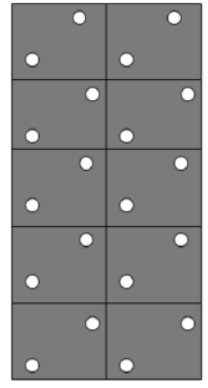

uniform

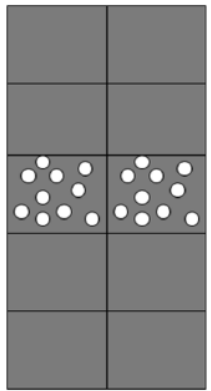

chustered
Gambar 1. Tiga pola dasar penyebaran spasial

Beberapa metode untuk mendeteksi pola spasial:

\section{a. Quadrat Analysis}

Metode quadrat analysis ini mengevaluasi distribusi pola titik dengan memeriksa perubahan kepadatan di suatu lokasi. Kepadatan yang diukur tersebut kemudian dibandingkan untuk mengetahui apakah pola titik-titik tersebut random, uniform, atau clustered. Langkah-langkah yang dilakukan dalam metode ini adalah membagi lokasi yang akan diteliti ke 
dalam suatu quadrats dan menghitung titik-titik yang berada dalam quadrats tersebut. Untuk menghitung ukuran maksimum quadrats tersebut adalah :

$$
=\frac{2 A}{n}
$$

Dengan $A$ adalah luas area dalam suatu lokasi dan $n$ adalah jumlah titik di lokasi tersebut. Terdapat beberapa pendekatan untuk mengetahui pola spasial melalui quadrat analysis, diantaranya pendekatan Variance-to-Mean Ratio (VTMR) dan pendekatan distribusi frekuensi.

\section{Variance-to-Mean Ratio (VTMR)}

Variance-to-Mean Ratio

(VTMR) menggunakan perhitungan rasio antara mean dan variance, dengan rumus :

$V T M R=\frac{S^{2}}{\bar{x}}$

- Apabila VTMR >1 maka akan cenderung berpola clustered. Hal ini menunjukkan bahwa ada suatu area yang memiliki banyak titik yang membentuk kluster-kluster dan ada area lainnya yang tidak terdapat titiktitik.

- Apabila VTMR mendekati 1 maka cenderung berpola random, dimana mean dan variance bernilai hampir sama.

- Apabila VTMR mendekati 0 atau kurang dari 1 maka cenderung berpola uniform, dimana variance bernilai mendekati nol. Hal ini menunjukkan bahwa titik-titik menyebar secara teratur di semua lokasi.

Pengujian hipotesis juga dapat dilakukan untuk mengetahui signifikansi pola pengelompokkan pada metode ini. Hipotesis yang digunakan adalah :

$\mathrm{H}_{0}$ : data tidak berpola mengelompok (clustered)

$\mathrm{H}_{1}$ : data berpola mengelompok (clustered)

Statistik uji: $\frac{(m-1) S^{2}}{\bar{x}}$
Tolak $\mathrm{H}_{0}$ jika statistik uji lebih dari $\chi_{(m-1), \alpha}^{2}$

2. Pendekatan Distribusi Frekuensi.

Metode Kolmogorov Smirnov menggunakan metode perbandingan antara distribusi frekuensi amatan dan distribusi frekuensi teoritik [4]. Hipotesis yang digunakan adalah :

$\mathrm{H}_{0}$ : tidak ada perbedaan distribusi frekuensi amatan dan teoritik

$\mathrm{H}_{1}$ : ada perbedaan distribusi frekuensi amatan dan teoritik

Statistik uji :

$D=\max \left|O_{i}-E_{i}\right|$

Tolak $\mathrm{H}_{0}$ jika $\mathrm{D}>\mathrm{D}_{\alpha}$

Proses random : menggunakan distribusi frekuensi Poisson

$P(x)=\frac{e^{-\lambda} \lambda^{x}}{x !}$ atau $P(x)=p(x-1) \frac{\lambda}{x}$

Dengan $\mathrm{x}$ adalah jumlah titik pada quadrat dan adalah rata-rata jumlah titik per quadrat.

Proses clustered : menggunakan pendekatan apabila jumlah titik per quadrat nol maka memiliki titik pola clustered m-1. Apabila memiliki m jumlah titik per quadrat maka memiliki titik pola clustered 1. Sedangkan yang lainnya adalah nol.

- Proses uniform : menggunakan rata-rata jumlah titik per quadrat.

\section{b. Matrik Pembobot Spasial}

Hubungan kedekatan (neighbouring) antar lokasi dinyatakan dalam matrik pembobot spasial W. Matrik pembobot spasial dapat ditentukan dengan beragam metode. Matriks bobot untuk tipe data spasial titik adalah: Inverse jarak, Kernel Gaussian, Fungsi pembobotan bisquare, dan Binary. Berdasarkan [6], matriks bobot untuk tipe data spasial area adalah: Rook Contiguity (Persinggungan sisi), Queen Contiguity (Persinggungan sisi-sudut), Linear Contiguity (Persinggungan tepi), Bhisop Contiguity (Persinggungan sudut), Double Linear Contiguity (Persinggungan dua tepi), dan 
Double Rook Contiguity (Persinggungan dua sisi).

\section{Spatial Autocorrelation}

Menurut [5] dalam Kartika [2] autokorelasi spasial adalah korelasi antara variabel dengan dirinya sendiri berdasarkan ruang atau dapat juga diartikan suatu ukuran kemiripan dari objek di dalam suatu ruang (jarak, waktu dan wilayah). Jika terdapat pola sistematik di dalam penyebaran sebuah variabel, maka terdapat autokorelasi spasial. Adanya autokorelasi spasial mengindikasikan bahwa nilai atribut pada daerah tertentu terkait oleh nilai atribut tersebut pada daerah lain yang letaknya berdekatan (bertetangga).

\section{Moran's I}

Moran's I mengukur korelasi satu variabel misal $\mathrm{x}\left(\mathrm{x}_{\mathrm{i}}\right.$ dan $\left.\mathrm{x}_{\mathrm{j}}\right)$ dimana $i \neq j$, $i=1,2, \ldots n, j=1,2, \ldots . n$ dengan banyak data sebesar $n$ [8]., maka formula dari Moran's $I$ adalah

$$
I=\frac{n}{S_{0}} \frac{\sum_{i} \sum_{j} w_{i j}\left(x_{i}-\bar{x}\right)\left(x_{j}-\bar{x}\right)}{\sum_{i}\left(x_{i}-\bar{x}\right)}
$$

$\bar{x}$ merupakan rata-rata dari variabel merupakan elemen dari matrik pembobot, dan $\mathrm{S}_{0}$ adalah jumlahan dari elemen matrik pembobot, dimana

$$
S_{0}=\sum_{i} \sum_{j} w_{i j}
$$

Nilai dari indeks $I$ ini berkisar antara -1 dan 1. Identifikasi pola menggunakan kriteria nilai indeks I, jika $\mathrm{I}>\mathrm{I} 0$, maka mempunyai pola mengelompok (cluster), jika $\mathrm{I}=\mathrm{I}_{0}$, maka berpola menyebar tidak merata (tidak ada autokorelasi), dan $\mathrm{I}<\mathrm{I}_{0}$, memiliki pola menyebar. I merupakan nilai ekspektasi dari I yang dirumuskan $\mathrm{E}(\mathrm{I})=\mathrm{I}_{0}=-1 /(\mathrm{n}-1)$ [4].

Pengujian hipotesis terhadap parameter I adalah sebagai berikut.

$\mathrm{H}_{0}$ : tidak ada autokorelasi spasial

$\mathrm{H}_{1}$ : terdapat autokorelasi positif (indeks
Moran's I bernilai positif/negatif)

Menurut [4] dalam [2] statistik uji dari indeks Moran's I diturunkan dalam bentuk statistik peubah acak normal baku. Hal ini didasarkan pada teori Dalil Limit Pusat dimana untuk $\mathrm{n}$ yang besar dan ragam diketahui maka $\mathrm{Z}(\mathrm{I})$ akan menyebar normal baku sebagai berikut.

$Z_{\text {hit }}=\frac{I-E(I)}{\sqrt{\operatorname{var}(I)}}$

dengan $I$ adalah indeks Moran's I, $Z_{\text {hitung }}$ adalah nilai statistik uji indeks Moran's I, $E(I)$ dan $\operatorname{var}(I)$ adalah nilai ekspektasi dan varians indeks Moran's I.

$\operatorname{var}(I)=\frac{n\left\{\left(n^{2}-3 n+3\right) S_{1}-n S_{2}+3 S_{0}^{2}\right\}}{(n-1)(n-2)(n-3) S_{0}^{2}}-\frac{k\left\{n(n-1) S_{1}-2 n S_{2}+6 S_{0}^{2}\right\}}{(n-1)(n-2)(n-3) S_{0}^{2}}-\frac{1}{(n-1)^{2}}$

dengan,

$$
\begin{aligned}
& S_{1}=\frac{1}{2} \sum_{i=1}^{n} \sum_{j=1}^{n}\left(w_{i j}+w_{j i}\right)^{2} \\
& k=\sum_{i=1}^{n}\left(x_{i}-\bar{x}\right)^{4} /\left(\left(\sum_{i=1}^{n} x_{i}-\bar{x}\right)^{2}\right)^{2} \\
& S_{2}=\sum_{i=1}^{n}\left(w_{i \cdot}+w_{\cdot i}\right)^{2}, w_{i \cdot}=\sum_{j=1}^{n} w_{i j}, w_{\cdot j}=\sum_{j=1}^{n} w_{j i}
\end{aligned}
$$

Pengujian ini akan menolak hipotesis awal jika nilai Zhitung $>\mathrm{Z}(\alpha)$ (autokorelasi positif) atau Zhitung $<-Z(\alpha)$ (autokorelasi negatif). Positif autokorelasi spasial megindikasikan bahwa antar lokasi pengamatan memiliki keeratan hubungan.

\section{LISA}

LISA merupakan pengidentifikasikan autokorelasi secara lokal dengan menemukan korelasi spasial pada setiap daerah. Pengidentifikasian autokorelasi juga menggunakan Moran's I secara lokal. Indeks Moran's I adalah sebagai berikut [7].

$I_{i}=z_{i} \sum_{i} w_{i j} z_{j}$

dimana $z_{i}$ dan $\mathrm{z}_{\mathrm{j}}$ merupakan deviasi dari nilai rata-rata, $z_{i}=\left(x_{i}-\bar{x}\right) / \delta . \delta$ adalah nilai standar deviasi dari $x_{i}$. Hipotesis yang digunakan adalah sebagai berikut. $\mathrm{H}_{0}$ : tidak ada autokorelasi spasial $\mathrm{H}_{1}$ : ada autokorelasi spasial 
Statistik Uji : $Z_{\text {hitung }}=\frac{I_{i}-E\left(I_{i}\right)}{\sqrt{\operatorname{var}\left(I_{i}\right)}}$

dengan $I_{i}$ merupakan indeks LISA, $Z_{\text {hitung }}$ merupakan statistik uji indeks LISA, $E\left(I_{i}\right)$ dan $\operatorname{var}\left(I_{i}\right)$ adalah nilai ekspektasi dan varians indeks LISA.

$E\left(I_{i}\right)=-w_{i} /(n-1)$

$\operatorname{var}\left(I_{i}\right)=w_{i}^{(2)} \frac{\left(n-\frac{m_{4}}{m_{2}^{2}}\right)}{(n-1)}-2 w_{i(k k l)} \frac{\left(2 m_{4} / m_{2}^{2}-n\right)}{(n-1)(n-2)}-\frac{w_{i}^{2}}{(n-1)^{2}}$

dengan,

$w_{i \cdot}^{2}=\sum_{j} w_{i j}^{2}, i \neq j$
$w_{i(k h)}=\sum_{k \neq i} \sum_{h \neq i} w_{i k} w_{i h}$
$w_{i \cdot}^{2}=\left(\sum_{j} w_{i j}\right)^{2}$

Tolak $\mathrm{H}_{0}$ jika nilai $\left|Z_{\text {hitung }}\right|>Z_{\alpha / 2}$.

\subsection{Moran's Scatterplot}

[4] menyebutkan bahwa Moran's Scatterplot adalah salah satu cara untuk menginterpretasikan statistik Indeks Moran. Moran's Scatterplot merupakan alat untuk melihat hubungan antara (nilai pengamatan yang sudah distandarisasi) dengan (nilai rata-rata daerah tetangga yang telah distandarisasi). Ilustrasi lebih lengkap dapat dilihat pada Gambar 2.

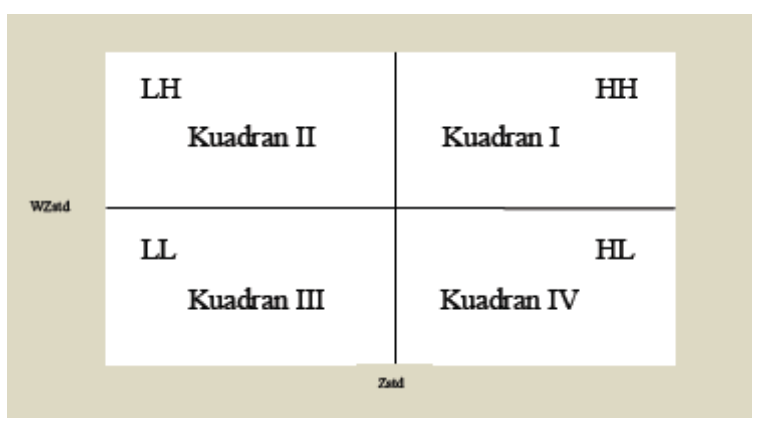

Gambar 2 Moran Scatterplot

Kuadran I (terletak di kanan atas) disebut High-High (HH), menunjukkan daerah yang mempunyai nilai pengamatan tinggi dikelilingi oleh daerah yang mempunyai nilai pengamatan tinggi. Kuadran II (terletak di kiri atas) disebut Low-High (LH), menunjukkan daerah dengan pengamatan rendah tapi dikelilingi daerah dengan nilai pengamatan tinggi.
Kuadran III (terletak di kiri bawah) disebut Low-Low (LL), menunjukkan daerah dengan nilai pengamatan rendah dan dikelilingi daerah yang juga mempunyai nilai pengamatan rendah. Kuadran IV (terletak di kanan bawah) disebut High-Low (HL), menunjukkan daerah dengan nilai pengamatan tinggi yang dikelilingi oleh daerah dengan nilai pengamatan rendah [2]. Moran's Scatterplot yang banyak Menempatkan pengamatan di kuadran $\mathrm{HH}$ dan kuadran LL akan cenderung mempunyai nilai autokorelasi spasial yang positif (cluster). Sedangkan Moran's Scatterplot yang banyak menempatkan pengamatan di kuadran HL dan LH akan cenderung mempunyai nilai autokorelasi spasial yang negatif.

\section{METODOLOGI PENELITIAN}

Data yang digunakan dalam penelitian ini adalah data proporsi data Produk Domestik Regional Bruto (PDRB). Data Produk Domestik Regional Bruto (PDRB) merupakan data sekunder yang diperoleh dari tugas akhir [9] dengan judul Pemodelan Produk Domestik Regional Bruto (PDRB) Sektor Industri di Provinsi Jawa Timur dengan Geographically weighted Regression (GWR) .

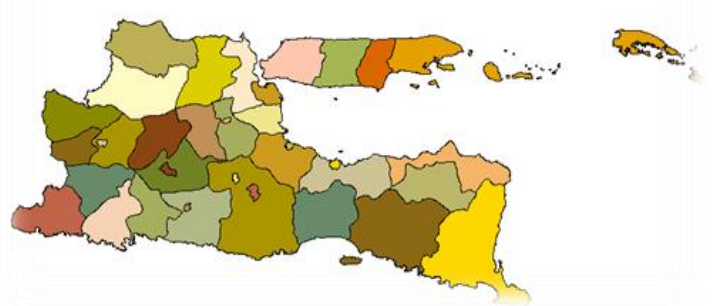

Gambar 3. Wilayah Penelitian (Jawa Timur)

Langkah-langkah analisis data penelitian ini adalah sebagai berikut:

1. Spatial Pattern Analysis.

a. Memetakan PDRB dalam suatu peta tematik. 
b. Analisis Spasial Pattern dengan metode Quadrat Analysis yaitu dengan Variance-to-Mean Ratio (VTMR).

2. Spatial Autocorrelation

a. Menghitung ukuran dependensi spasial (autocorrelation) menggunakan indeks Moran's I dan LISA

c. Menguji dependensi spasial indeks Moran's I dan LISA

d. Membuat dan menganalisis Moran's Scatterplot

\section{HASIL DAN PEMBAHASAN}

\subsection{Spasial Pattern Proporsi PDRB sektor Industri di Provinsi Jawa Timur}

Sebaran Proporsi PDRB sektor Industri di Provinsi Jawa Timur cenderung berpola clustered. Hal ini ditunjukkan dengan nilai VTMR > 1 (Tabel 1). Nilai ini menunjukkan bahwa ada suatu area / kabupaten yang proporsi PDRB bernilai tinggi dan ada juga area dengan proporsi PDRB bernilai rendah.

Tabel 1. Nilai VTMR dan Statistik Uji

\begin{tabular}{c|r}
\hline $\bar{X}$ & 0,166 \\
$S^{2}$ & 2,085825 \\
VTMR & 12,54334 \\
Statistik & 464,1034 \\
Uji $=\chi^{2}$ & \\
$\chi_{37 ; 0,05}^{2}$ & 55,758 \\
\hline
\end{tabular}

Berdasarkan pengujian, didapatkan nilai $\chi^{2}>\chi_{37 ; 0,05}^{2}$. Sehingga kesimpulannya adalah data berpola mengelompok (clustered).

Dengan menggunakan peta tematik, sebaran data dari PDRB di Jawa Timur dapat dilihat pada Gambar 4 di bawah ini. Semakin gelap warna pada peta, menunjukkan bahwa kabupaten/kota tersebut memiliki proporsi PDRB semakin tinggi. Kabupaten/Kota yang memiliki nilai PDRB tinggi ditunjukkan oleh kode area 14, 15, 16, 25 dan 78. Kabupaten/Kota tersebut yakni Pasuruan, Sidoarjo, mojokerto, Gresik dan Surabaya. Jika dilihat dari letak kelima Kabupaten/kota tersebut yang berdekatan, maka hal ini semakin memperkuat hasil analisis diatas yang menyimpulkan bahwa sebaran Proporsi PDRB sektor Industri di Provinsi Jawa Timur cenderung berpola clustered. Jika sebaran PDRB berpola mengelompok atau clustered, maka tingkat pertumbuhan perekonomian masyarakat di Jawa Timur juga berpola clustered.

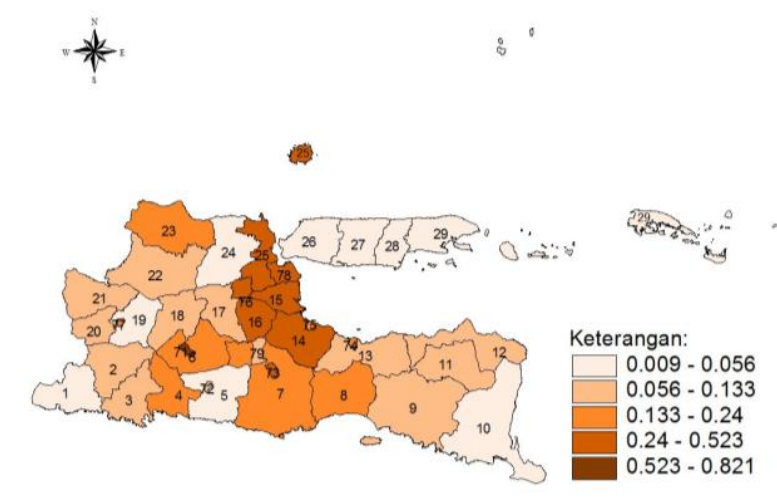

Gambar 4 Peta Tematik Proporsi PDRB sektor Industri

di Provinsi Jawa Timur

Hal ini juga terjadi pada Kabupaten/kota yang memiliki PDRB rendah. Berdasarkan Gambar 4, semakin cerah warna peta, menunjukkan bahwa proporsi PDRB di kabupaten/kota tersebut rendah. Kabupaten/Kota yang memiliki nilai PDRB rendah ditunjukkan oleh kode area 26, 27,28, dan 29. Kabupaten/Kota tersebut yakni Bangkalan, Pamekasan, Sampang, dan Sumenep. Jika dilihat dari letak keempat Kabupaten/kota tersebut yang berdekatan, hal ini juga memperkuat hasil analisis yang menyimpulkan bahwa sebaran Proporsi PDRB sektor Industri di Provinsi Jawa Timur cenderung berpola clustered.

\subsection{Spasial Autocorrelation Proporsi PDRB sektor Industri di Provinsi Jawa Timur}




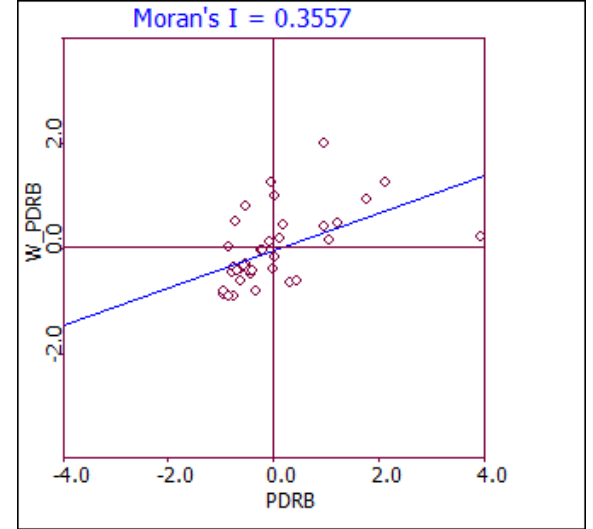

Gambar 5. Moran's Scatterplot Proporsi PDRB sektor Industri di Provinsi Jawa Timur

$$
\begin{aligned}
E(I)=I_{0} & =-1 /(n-1) \\
& =-1 /(38-1) \\
& =-0,027
\end{aligned}
$$

Pola sebaran data juga dapat dilihat berdasarkan nilai Moran's I. karena nilai I $(0,3557)>\mathrm{I}_{0}$, maka dapat disimpulkan bahwa pola sebarannya adalah mengelompok. Selain itu, nilai Moran's I menunjukkan bahwa secara global, tidak ada autokorelasi spasial pada proporsi PDRB sektor Industri di Provinsi Jawa Timur. Hal ini diperlihatkan dengan nilai Moran's I yang mendekati nol.

Berdasarkan Gambar 5, terdapat 9 kabupaten/kota menyebar pada kuadran HH dan 6 kabupaten/kota di LH, 20 kabupaten/kota menyebar pada kuadran LL, serta 2 kabupaten/kota menyebar pada kuadran HL. Kuadran 1 (HH) menunjukkan kabupaten/kota yang proporsi PDRB tinggi berada di antara kabupaten/kota yang proporsi PDRB tinggi pula. Kuadran 2 (LH) menunjukkan kabupaten/kota dengan proporsi PDRB rendah berada di antara kabupaten/kota dengan proporsi PDRB tinggi. Kuadran 3 (LL) menunjukkan kabupaten/kota dengan proporsi PDRB rendah berada di antara kabupaten/kota yang jumlah proporsi PDRB rendah. Sementara kuadran 4 (HL) menunjukkan kabupaten/kota yang proporsi PDRB tinggi berada di antara kabupate/kota yang jumlah proporsi PDRB rendah. Kuadran $\mathrm{HH}$ dan LL mengindikasikan adanya autokorelasi positif dan kuadran LH dan HL mengindikasikan adanya autokorelasi spasial negatif.

Tabel 2. Autokorelasi Parsial dengan LISA

\begin{tabular}{llll}
\hline Kabupaten & $\begin{array}{l}\text { P- } \\
\text { Value }\end{array}$ & Kabupaten & $\begin{array}{l}\text { P- } \\
\text { Value }\end{array}$ \\
\hline Pacitan & 0,208 & Malang (Kota) & 0,248 \\
Ponorogo & 0,062 & Probolinggo & 0,486 \\
Trenggalek & 0,274 & Pasuruan (Kota) & 0,166 \\
Tulungagung & 0,176 & Mojokerto(Kota) & 0,090 \\
Lumajang & 0,370 & Madiun (Kota) & 0,158 \\
Bondowoso & 0,190 & Surabaya (Kota) & 0,180 \\
Pasuruan & 0,158 & Batu (Kota) & 0,140 \\
Jombang & 0,478 & Blitar & 0,430 \\
Nganjuk & 0,228 & Kediri & 0,140 \\
Madiun & 0,152 & Mojokerto & 0,082 \\
Kabupaten & $\mathbf{P -}$ & Kabupaten & P- \\
& Value & & Value \\
Magetan & 0,286 & Banyuwangi & 0,180 \\
Ngawi & 0,068 & Gresik & 0,054 \\
Bojonegoro & 0,114 & Jember & 0,262 \\
Tuban & 0,122 & Malang & 0,290 \\
Lamongan & 0,132 & Probolinggo & 0,476 \\
Bangkalan & 0,024 & Sampang & 0,010 \\
Pamekasan & 0,004 & Sidoarjo & 0.006 \\
Kediri & 0,252 & Situbondo & 0,236 \\
(Kota) & & & 0,048 \\
Blitar & 0,104 & Sumenep & \\
(Kota) & & & \\
\hline Ket: Signifiran &
\end{tabular}

Ket: $*=$ Signifikan pada $\alpha=5 \%$

Berdasarkan LISA, hanya Kabupaten Bangkalan, Pamekasan, Sampang, Sumenep, dan Sidoarjo yang memiliki autokorelasi spasial dengan kabupaten/kota lain yang berdekatan. Sementara untuk kabupaten/kota lainnya tidak memiliki autokorelasi spasial, karena p-value $>\alpha$. 


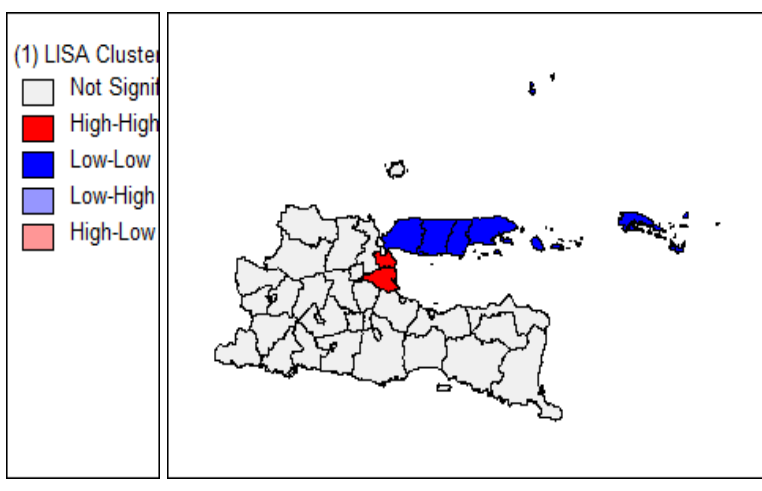

Gambar 6. Peta Pengelompokan Wilayah Berdasarkan LISA

Gambar 6 menunjukkan bahwa Surabaya dan Sidoarjo berada di $\mathrm{HH}$. Sementara Bangkalan, Sampang, Pamekasan dan Sumenep berada di LL. Hal ini menunjukkan bahwa Surabaya, Sidoarjo, Bangkalan, Sampang, Pamekasan dan Sumenep memiliki autokorelasi positif dengan kabupaten disekitarnya, ketika proporsi PDRB di kabupaten disekitarnya tinggi, maka proporsi PDRB di Surabaya dan Sidoarjo juga tinggi. Sehingga hal ini juga mempengaruhi pertumbuhan perekonomian di Kabupaten/kota tersebut. ketika pertumbuhan perekonomian di kabupaten disekitarnya cepat, maka pertumbuhan perekonomian di Surabaya dan Sidoarjo juga cepat. Begitupula untuk Kabupaten Bangkalan, Sampang, Pamekasan dan Sumenep, ketika proporsi PDRB di kabupaten disekitarnya rendah, maka proporsi PDRB di empat kabupaten tersebut juga rendah.

\section{KESIMPULAN}

Berdasarkan hasil analisis dan pembahasan, maka dapat disimpulkan bahwa dengan analisis spatial pattern proporsi PDRB di Provinsi Jawa Timur cenderung berpola cluster, dimana mengelompok di kabupaten-kabupaten tertentu. Jika sebaran PDRB berpola mengelompok atau clustered, maka tingkat pertumbuhan perekonomian masyarakat di
Jawa Timur juga berpola clustered. Sementara hasil pengujian dengan Moran's I menunjukkan bahwa tidak ada autokorelasi spasial di Provinsi Jawa Timur pada data proporsi PDRB. Sementara secara lokal, kabupaten yang memiliki autokorelasi spasial hanyalah Kabupaten Bangkalan, Pamekasan, Sampang, dan Sumenep. Ketika proporsi PDRB di kabupaten disekitarnya rendah, maka proporsi PDRB di empat kabupaten tersebut juga rendah.

\section{DAFTAR PUSTAKA}

Godam, (2006), "Faktor Pendukung dan Penghambat Industri BisnisPerkembangan dan Pengembangan Industry-Ilmu Sosial Ekonomi Pembangunan, http://organisasi.org/faktor_penduku ng_dan_penghambat_industri_bisnis _perkembangan_dan_pembangunan _industry_ilmu_sosial_ekonomi_pe mbangunan, [24 Februari, 2010].

Kartika Yoli, (2007), "Pola Penyebaran Spasial Demam Berdarah Dengue di Kota Bogor tahun 2005”, [Tugas Akhir] Institut Pertanian Bogor.

Krebs, C.J, (1989), Ecological Methodology, Harper Collins Publisher, Inc. New York.

Lee Jay \&Wong S W David, (2000), Statistical Analysis with Arcview GIS, John Willey \& Sons, INC: United Stated of America.

Lembo, A. J, (2006), "Spatial Autocorrelation", Cornell University, http://www.css.cornell.edu/courses/6 20/lecturer9.ppt [25 Oktober, 2008]

LeSage, J.P. dan Pace, R.K., (2009), Introduction to Spasial Econometrics, R Press, Boca Ration.

Ludwig, J.A, and J.F. Reynolds, (1988), Statistical Ecology, John Wiley \& Sons, Inc. Canada. 
Paradis, Emanuel, (2010), “Moran's Autocorrelation, http://hosho. ees.hokudai.ac.jp/ kubo/Rdoc/librar y/ape/html/MoranI.html September,2010].

Rohmah, Elya Nur. 2011. Pemodelan Produk Domestik Regional Bruto (PDRB) Sektor Industri di Provinsi Jawa Timur dengan Geographically weighted Regression (GWR).[Tugas Akhir] Institut Teknologi Sepuluh Nopember.

Singgih, M.R. dan Hennytasari, E., (2009). Pemilihan Alternatif Perbaikan Kinerja Lingkungan Sektor Industri Potensial di Jawa Timur dengan Metode Economic Input-Output LifeCycle Assessment (eio-lca) Dan analytic network process (anp), http://www.its.ac.id/personal/files/pu b/2499-mosesie-

131694604_1150EIO-

LCA\%20Moses\%20\%20Evani.pdf. [28 Februar 2011]

Tottrup, C, et al, (2009), "Putting Child Mortality On Map", Towards an Understanding of Inequity In Health, Vol.14 No.6, Hal 653-662. 